\title{
Pay Your Fair Share? - An Empirical Analysis of Corporate Social Responsibility and Taxes
}

\author{
Richard McGowan \\ Boston College \\ John F. Mahon \\ University of Maine
}

This paper provides an empirical study of the relationship between Corporate Social Responsibility (CSR) perceptions and the effective taxes rates This study took data from over 2,600 firms (U.S. based, minimum market cap of $\$ 500$ million). The data consisted of average effective tax rates (2010-2017), cash taxes paid from the same period, their 2017 ESG Score (converted from letter grade to number scale), their 2017 RepTrack score, their Fortune's Most Admired Companies Ranking, and their 2017 Fortune Social Responsibility Peer Ranking.

Keywords: Corporate Social Responsibility, Tax Rates, Public Perception of Taxes Paid by Firms

\section{INTRODUCTION}

Taxation has been a greatly contested issue over the last few decades, particularly in the United States, which had the third highest general top marginal corporate income tax rate in the world (Pomerleau 2015). Politicians and citizens alike have debated the subject of corporate taxation in America, one side claiming that high taxes are an inhibitor to the US economy while the other side seeking even higher corporate taxation to fund public goods such as education and healthcare.

The issue of corporate taxation in the United States comes down to its effect on stakeholders, mainly the conflict between shareholder interest and a thriving public sector. Companies have a responsibility to maximize shareholder value, and thus have an incentive to pay as little in taxes as is allowed by the law. The combination of a high US corporate tax rate and this fiduciary responsibility to shareholders has spurned corporations to act creatively to avoid paying the full effective corporate tax rate. Over the last few decades, companies have been exploiting legal loopholes, such as the use of tax havens, shell corporations, tax inversions and the like, to legally avoid paying the full amount of taxes on their income. Tax avoidance is widespread, and due to political ideology and lobbying power, little has been done to eradicate these practices. 


\section{THE ISSUE OF TAXATION AND PUBLIC PERCEPTION}

Firms generally dodge taxes in perfectly legal ways, including the use of accelerated depreciation, industry specific tax subsidies, stock option reporting, and offshore tax sheltering. However, the ethics of these tax maneuvers have been debated by politicians from both parties and by citizens in general.

On one side of the debate, critics of the US tax code complain that corporate taxes in the US were too high to begin with, and that legal avoidance of taxes was not unethical. They often cite that the alternative to tax dodging would be to move operations overseas, which would be worse for the United States than the foregone tax revenue to the government. Others argue that corporate taxes shouldn't exist in general, because taxing a corporate entity and the individual is a form of double taxation that inhibits economic growth and global competitiveness of corporations (Thorndike 2012).

On the other side of the debate are those who believe that the current culture of corporate tax dodging poses an existential threat to the US's ability to collect taxes from the most profitable companies that receive many benefits of being headquartered in America. They claim that, just as rich individuals should not be entitled to unfair tax breaks, so too should corporations be held to the standard of paying their fair share of taxes (McIntyre, et al. 2011).

The latter viewpoint has been expressed by a plethora of social movements that aim to expose and dismantle corporations for being "greedy". Movements such as Citizens for Tax Justice, Occupy Wall Street, New York Communities for Change, and the Working Families Party are all movements that rally to ensure that the $1 \%$ of America's wealthiest and some of the largest corporations pay their fair share of federal and state taxes (Kilkenny 2012). It is no surprise that there is concern; a 2011 study showed that out of 280 of the largest corporations in the US, only a quarter of companies paid three-year effective tax rates of more than 30 percent, while $35 \%$ had an effective tax rate of less than 10 percent, with many corporations paying zero or even negative tax rates over the 2008-2010 time period. This issue has been covered extensively by the American media, and has been at the forefront of the debates during the 2020 GOP and Democratic Primaries.

It would seem that with the outpouring of attention given to this issue in the last decade, corporations that are known tax dodgers would receive a negative public reputation from individuals and publications alike. Although much has been done to identify tax dodgers and condemn the practice of using tax loopholes, less has been done to analyze the relationship between how much a company pays in taxes, and how they are perceived as a socially responsible corporation by various stakeholders. This paper seeks to understand the connection (or disconnect) between corporate taxes and Corporate Social Responsibility (CSR) metrics for major corporations. In essence we are interested not in the "good" or "bad" of tax avoidance but rather whether the general public cares about which firms pay taxes and how the general public views those firms.

\section{Comparing Tax Rates across Firms and Social Responsibility Metrics}

One important consideration to take into account is how to measure tax rates for corporations, given that the firms in the study were of different sizes, in different industries, and headquartered in different states. Additionally, firm taxes can be measured in a variety of ways, based on an assortment of accountancy factors. There has been some debate as to whether the income tax expense from a firm's income statement is a proper representation of how much a firm actually pays in taxes. The closest alternative to income tax expense ("Book Tax") is cash income taxes paid ("Cash Tax"). Although cash tax is useful for its own purposes, it is impossible to compare these taxes across firms, because all of the companies in our study have different levels of multinational operations, and could be incorporated in different states. Therefore, it was deemed that income tax expense is the most direct, albeit not perfect, way of comparing how much companies pay in taxes. This study calculated a five-year average effective tax rate from 2010 to 2014 by dividing income tax expense by pretax income.

In deciding how to gauge a company's reputation for social responsibility, there were several sources to consider. This study assessed several publications focused on evaluating corporate reputations. Three distinct rankings were chosen based on the different ways in which they obtained social responsibility 
opinions. Fortune's Most Admired Companies surveyed industry professionals, MSCI KLD ratings were conducted using propriety research, and RepTrak 100 rankings stem from interviews with over 61,000 everyday consumers. These rankings are all unique in their methodologies and surveying techniques, providing a comprehensive picture of company reputations.

Fortune's Most Admired list consists of the 15 largest companies for each international industry and the 10 largest for each US industry, covering a total of 668 companies from 29 countries. The publication then surveyed 4,104 industry professionals and analysts to rate companies in their own industry based on nine criteria, from investment value to social responsibility. The survey also asked them which ten companies they admired most in any industry (Elam 2016). The data used in the regressions consists of both the overall score and a ratio of peer rank within the social responsibility section. For example, Boeing is the highest rated Aerospace and Aviation company overall, with a score of 7.49 , but is the 3rd ranked for Social Responsibility within the industry, giving it a Social Responsibility score of 3/15 or 0.2.

The MSCI KLD ESG ratings are purposed to help conscious investors identify socially responsible firms whose ethical commitments stand out amongst their peers. KLD gives scores on five criteria: Environment, Community \& Society, Employees \& Supply Chain, Customers, and Governance \& Ethics (MSCI 2016). The KLD 400 Index also excludes any firms that engage in unethical or negative practices (Turner 2013). Overall, firms are given a letter grade (CCC, B, BB, BBB, A, AA, AAA) based on the aggregate ESG scores from each category (Lee 2015). In running the regressions, these ESG grades were converted to a numerical scale of 1-7.

The Reputation Institute's' RepTrak 100 rankings profile companies based on Leadership, Performance, Products/Services, Innovation, Workplace, Governance, and Citizenship. The Institute obtains data from over 61,000 consumer interviews based on how the top 100 global companies meet expectations and gain their trust and support. Ultimately scores are aggregated and the 100 firms are ranked against their peers (RepTrak Institute 2016).

\section{THE DATA SET}

In order to best understand the relationship between corporate reputation and how much they pay in taxes, this study took data from over 2,600 firms. Each firm in the study was a United States based firm that had a minimum market cap of $\$ 500$ million. The firm data consisted of their average effective tax rate from 2010-2015, their average cash taxes paid from the same period, their 2015 ESG Score (converted from letter grade to number scale), their 2015 RepTrack score, their Fortune's Most Admired Companies Ranking, and their 2015 Fortune Social Responsibility Peer Ranking. The data set is summarized as follows in Table 1:

TABLE 1

\section{SUMMARY OF THE DATA SET}

\begin{tabular}{|l|c|c|c|c|c|}
\hline & $\mathrm{N}$ & Minimum & Maximum & Mean & Std. Deviation \\
\hline Average Revenue & 2,695 & -60.60 & $444,277.60$ & $4,868.61$ & $17,997.57$ \\
Average EBT & 2,695 & $-2,020.90$ & $62,573.60$ & 598.84 & $2,489.80$ \\
Average Net Income & 2,695 & $-3,687.30$ & $36,326.00$ & 490.36 & $1,928.12$ \\
Average Tax Rate & 2,611 & 0.00 & $1,860.50$ & 27.79 & 88.25 \\
Average Cash Taxes Paid & 2,312 & $-1,680.00$ & $22,739.00$ & 144.96 & 730.88 \\
Market Capitalization & 2,984 & 500.60 & $538,536.00$ & $8,295.01$ & $26,982.52$ \\
ESG Score & 1,812 & 1.00 & 7.00 & 3.42 & 1.25 \\
RepTrack & 42 & 63.97 & 75.40 & 67.23 & 2.65 \\
Fortune & 398 & 2.27 & 8.80 & 6.00 & 0.93 \\
Social Responsibility Peer Rank & 372 & 1.00 & 15.00 & 5.72 & 3.46 \\
\hline
\end{tabular}


It is insightful to see that the average tax rate among the 2,611 firms is around 28\%, which is below the standard 35\% corporate tax rate during the time period that was studied. This is evidence of the culture of tax avoidance that was previously discussed. Several firms paid unusually high tax rates during the years 2010-2015, which is why the standard deviation for Average Tax Rate is so high. There was also a significant amount of firms that didn't pay any taxes during this time period, which reinforces the trend from McIntyre's 2011 study, which saw 11\% of corporations paying zero or negative taxes from 2008-2010 (McIntyre, et al. 2011).

It is duly noted that the number of firms in the four CSR rankings is below the total number of firms analyzed in this study. As shown by this table the number of firms in each CSR ranking category varies considerably. The ESG ratings were the most comprehensive, with 1,812 firms included. The Fortune and RepTrak Rankings were less thorough, which isn't surprising given that they are surveys, as opposed to the MSCI ESG ratings, which were done using proprietary research. The correlation matrix for this analysis is shown in Table 2 below.

The first part in analyzing this data was to evaluate the correlations between the key variables in the study. As expected, the cash taxes paid measure was highly correlated to both survey rankings (Fortune and RepTrak). However, this resulted more from a correlation between firm size in revenue (thus more taxes) and public reputation. When evaluating these rankings from an effective tax rate perspective, the relationship does not exist, outside of the Fortune score, which actually showed a slightly negative correlation between effective tax rate and corporate reputation. Outside of the Fortune-Tax Rate correlation, these results were discouraging for finding any relationship between corporate taxes and CSR ratings. This data is shown in Table 3.

TABLE 2

CORRELATION MATRIX

\begin{tabular}{|c|c|c|c|c|c|c|c|}
\hline & & $\begin{array}{l}\text { Average } \\
\text { Tax Rate }\end{array}$ & $\begin{array}{c}\text { Average } \\
\text { Cash Taxes } \\
\text { Paid }\end{array}$ & ESGS core & RepTrack & Fortune & $\begin{array}{c}\text { Social } \\
\text { Responsibility Peer } \\
\text { Rank }\end{array}$ \\
\hline Average Tax Rate & \begin{tabular}{|c|} 
Pearson Correlation \\
Sig. (2-tailed) \\
$\mathrm{N}$
\end{tabular} & $\begin{array}{c}1.00 \\
2,611.0\end{array}$ & $\begin{array}{c}0.01 \\
0.77 \\
2,229.00\end{array}$ & $\begin{array}{c}0.01 \\
0.72 \\
1,751.00\end{array}$ & $\begin{array}{l}-0.04 \\
0.82 \\
42.00\end{array}$ & $\begin{array}{c}-.118^{\circ} \\
0.02 \\
393\end{array}$ & $\begin{array}{c}0 \\
0 \\
368\end{array}$ \\
\hline Average Cash Taxes Paid & $\begin{array}{c}\text { Pearson Correlation } \\
\text { Sig. (2-tailed) } \\
\mathrm{N}\end{array}$ & $\begin{array}{c}0.01 \\
0.77 \\
2,229.00\end{array}$ & $\begin{array}{c}1.00 \\
2,312.00\end{array}$ & $\begin{array}{c}0.04 \\
0.07 \\
1,809.00\end{array}$ & $\begin{array}{l}.596 \% \\
0.00 \\
42.00\end{array}$ & $\begin{array}{c}369^{\circ} \\
0 \\
398\end{array}$ & $\begin{array}{c}-.316^{\circ \bullet} \\
0 \\
372\end{array}$ \\
\hline ES GS core & $\begin{array}{c}\text { Pearson Correlation } \\
\text { Sig. (2-tailed) } \\
\mathrm{N} \\
\end{array}$ & $\begin{array}{c}0.01 \\
0.72 \\
1,751.00\end{array}$ & $\begin{array}{c}0.04 \\
0.07 \\
1,809.00\end{array}$ & $\begin{array}{c}1.00 \\
1,812.00 \\
\end{array}$ & $\begin{array}{r}0.17 \\
0.28 \\
42.00\end{array}$ & $\begin{array}{c}.139^{\circ \bullet} \\
0.009 \\
351\end{array}$ & $\begin{array}{c}-.210^{\circ \bullet} \\
0 \\
327 \\
\end{array}$ \\
\hline RepTrack & $\begin{array}{c}\text { Pearson Correlation } \\
\text { Sig. (2-tailed) } \\
\mathrm{N}\end{array}$ & $\begin{array}{l}-0.04 \\
0.815 \\
42.00\end{array}$ & $\begin{array}{c}.596^{\circ} \\
0 \\
42.00\end{array}$ & $\begin{array}{l}0.17 \\
0.278 \\
42.00\end{array}$ & $\begin{array}{l}1.00 \\
42.00\end{array}$ & $\begin{array}{c}.490^{\circ} \\
0.001 \\
40\end{array}$ & $\begin{array}{c}0 \\
0.156 \\
40\end{array}$ \\
\hline Fortune & \begin{tabular}{|c} 
Pearson Correlation \\
Sig. (2-tailed) \\
$\mathrm{N}$ \\
\end{tabular} & $\begin{array}{c}-.118^{*} \\
0.02 \\
393 . \infty\end{array}$ & $\begin{array}{l}.369^{\circ \bullet} \\
0 . \infty 0 \\
398 . \infty\end{array}$ & $\begin{array}{c}.139^{\circ} \\
0.01 \\
351.00\end{array}$ & $\begin{array}{l}.490 \% \\
0.00 \\
40.00\end{array}$ & $\begin{array}{r}1 \\
398 \\
\end{array}$ & $\begin{array}{c}-.712^{\bullet} \\
0 \\
372\end{array}$ \\
\hline Social Responsibility Peer Rank & $\begin{array}{c}\text { Pearson Correlation } \\
\text { Sig. (2-tailed) } \\
\mathrm{N}\end{array}$ & $\begin{array}{c}0.08 \\
0.11 \\
368.00\end{array}$ & $\begin{array}{c}-.316^{\bullet} \\
0.00 \\
372.00\end{array}$ & $\begin{array}{c}-.210^{\circ} \\
0 . \infty \\
327 . \infty\end{array}$ & $\begin{array}{r}-0.23 \\
0.16 \\
40.00\end{array}$ & $\begin{array}{c}-.712^{\bullet} \\
0 \\
372\end{array}$ & $\begin{array}{c}1 \\
372\end{array}$ \\
\hline
\end{tabular}

- Correlation is significant at the 0.05 level (2-tailed).

- Correlation is significant at the 0.01 level (2-tailed). 
TABLE 3

AVERAGE TAX RATES AND ESG SCORE QUARTILES

\begin{tabular}{|c|c|c|c|c|c|c|c|c|}
\hline \multirow{2}{*}{$\begin{array}{l}\text { ESG Score } \\
\text { Quartile }\end{array}$} & \multirow[b]{2}{*}{$\mathrm{N}$} & \multirow[b]{2}{*}{ Mean } & \multirow[b]{2}{*}{ Std. Deviation } & \multirow[b]{2}{*}{ Std. Error } & \multicolumn{2}{|c|}{$\begin{array}{c}95 \% \text { Confidence Interval for } \\
\text { Mean }\end{array}$} & \multirow[b]{2}{*}{ Minimum } & \multirow[b]{2}{*}{ Maximum } \\
\hline & & & & & Lower Bound & Upper Bound & & \\
\hline 1 & 466 & $32.9 \%$ & $94.4 \%$ & $4.4 \%$ & $24.3 \%$ & $41.5 \%$ & $0.0 \%$ & $1623.3 \%$ \\
\hline 2 & 499 & $32.0 \%$ & $55.8 \%$ & $2.5 \%$ & $27.1 \%$ & $36.9 \%$ & $0.0 \%$ & $909.4 \%$ \\
\hline 3 & 444 & $41.4 \%$ & $142.4 \%$ & $6.8 \%$ & $28.1 \%$ & $54.7 \%$ & $0.0 \%$ & $1860.5 \%$ \\
\hline 4 & 342 & $33.8 \%$ & $74.8 \%$ & $4.0 \%$ & $25.8 \%$ & $41.8 \%$ & $0.0 \%$ & $1342.9 \%$ \\
\hline Total & 1751 & $35.0 \%$ & $97.4 \%$ & $2.3 \%$ & $30.4 \%$ & $39.5 \%$ & $0.0 \%$ & $1860.5 \%$ \\
\hline
\end{tabular}

The ESG measure is interesting because it consists of the most robust data available in the study $(\mathrm{n}=$ 1751). Because the data set includes both small and large cap companies, the standard deviations from this set are much larger than the other three sets. The average tax rate is consistent with the $35 \%$ corporate tax rate in the US. To test whether there was a significant difference between average tax rates across quartile groups, this study ran a one-way ANOVA to test whether there was a statistically significant difference in average tax rate across groups as shown in Table 4 below.

TABLE 4

ANOVA

Average Tax Rate
\begin{tabular}{|l|c|c|c|c|c|}
\hline & Sum of Squares & df & Mean Square & F & Sig. \\
\hline Between Groups & $25,282.63$ & 3.00 & $8,427.54$ & 0.89 & 0.45 \\
Within Groups & $16,584,829.89$ & $1,747.00$ & $9,493.32$ & & \\
Total & $16,610,112.52$ & $1,750.00$ & & & \\
\hline
\end{tabular}

When looking at the means test, the results are very insignificant, suggesting no statistical difference in average effective tax rates between the quartiles of ESG ratings. This shows that professional CSR ratings are not statistically affected by how much firms pay in taxes (see Table 5 below).

TABLE 5 AVERAGE TAX RATES AND REPTRAK RATINGS

\begin{tabular}{|c|c|c|c|c|c|c|c|c|}
\hline \multirow{2}{*}{$\begin{array}{c}\text { Quartile for } \\
\text { RepTrak } \\
\text { Rankings }\end{array}$} & \multirow{2}{*}{$\mathrm{N}$} & \multirow{2}{*}{ Mean } & \multirow{2}{*}{$\begin{array}{c}\text { Std. } \\
\text { Deviation }\end{array}$} & \multirow{2}{*}{ Std. Error } & \multicolumn{2}{|c|}{$\begin{array}{c}95 \% \text { Confidence Interval for } \\
\text { Mean }\end{array}$} & \multirow{2}{*}{ Minimum } & \multirow{2}{*}{ Maximum } \\
\hline & & & & & Lower Bound & Upper Bound & & \\
\hline 1 & 10 & $22.0 \%$ & $11.1 \%$ & $3.5 \%$ & $14.0 \%$ & $30.0 \%$ & $0.0 \%$ & $35.8 \%$ \\
\hline 2 & 11 & $62.8 \%$ & $128.3 \%$ & $38.7 \%$ & $-23.4 \%$ & $149.0 \%$ & $14.6 \%$ & $449.1 \%$ \\
\hline 3 & 11 & $29.3 \%$ & $10.1 \%$ & $3.0 \%$ & $22.5 \%$ & $36.1 \%$ & $13.2 \%$ & $50.5 \%$ \\
\hline 4 & 10 & $26.3 \%$ & $6.4 \%$ & $2.0 \%$ & $21.7 \%$ & $30.9 \%$ & $19.6 \%$ & $38.0 \%$ \\
\hline Total & 42 & $35.6 \%$ & $66.0 \%$ & $10.2 \%$ & $15.1 \%$ & $56.2 \%$ & $0.0 \%$ & $449.1 \%$ \\
\hline
\end{tabular}

The RepTrak descriptive statistics show that even with a small number of observations $(n=42)$, there is still valuable information that can be learned about firms. The RepTrak quartiles seemed to be relatively stable in terms of Average Tax Rate, which had a much lower average standard deviation than the other rankings. This makes sense, considering that all 42 of the companies in the survey were large 
cap, well-known names. Other than one firm paying a $449 \%$ tax and others paying $0 \%$, there were no anomalies in this sample (see Table 6 below).

TABLE 6

ANOVA

Average Tax Rate
\begin{tabular}{|l|c|c|c|c|c|}
\hline & Sum of Squares & df & Mean Square & F & Sig. \\
\hline Between Groups & $11,264.53$ & 3.00 & $3,754.84$ & 0.85 & 0.47 \\
Within Groups & $167,178.67$ & 38.00 & $4,399.44$ & & \\
Total & $178,443.20$ & 41.00 & & & \\
\hline \hline
\end{tabular}

The ANOVA table tells the same story as the ESG ratings: tax rates do not significantly vary across quartiles of CSR ratings. With an F-statistic of 0.85 , once again, the hypothesis that these firms are the same cannot be rejected. Hence the average amount of taxes that firms pay are not statistically significantly different.

Given that there was a negative correlation between effective tax rate and Fortune Rankings, this group was particularly interesting to observe (see Table 7 below). At first glance, the average tax rate seemed to trend downward as firms became higher on the Fortune's Most Admired List. However, their standard deviations show that proving them as statistically different is a challenge (see Table 8 below):

TABLE 7

AVERAGE TAX RATE AND FORTUNE RANKINGS

\begin{tabular}{|c|c|c|c|c|c|c|c|c|}
\hline \multirow{2}{*}{$\begin{array}{l}\text { Quartile } \\
\text { for } \\
\text { Fortune } \\
\text { Rankings }\end{array}$} & \multirow{2}{*}{$\mathrm{N}$} & \multirow{2}{*}{ Mean } & \multirow{2}{*}{$\begin{array}{c}\text { Std. } \\
\text { Deviation }\end{array}$} & \multirow{2}{*}{ Std. Error } & \multicolumn{2}{|c|}{$\begin{array}{l}95 \% \text { Confidence Interval for } \\
\text { Mean }\end{array}$} & \multirow{2}{*}{ Minimum } & \multirow{2}{*}{ Maximum } \\
\hline & & & & & Lower Bound & Upper Bound & & \\
\hline 1 & 96 & $52.2 \%$ & $144.9 \%$ & $14.8 \%$ & $22.9 \%$ & $81.6 \%$ & $0.0 \%$ & $1342.9 \%$ \\
\hline 2 & 97 & $34.8 \%$ & $47.4 \%$ & $4.8 \%$ & $25.3 \%$ & $44.4 \%$ & $0.5 \%$ & $477.0 \%$ \\
\hline 3 & 101 & $33.8 \%$ & $43.8 \%$ & $4.4 \%$ & $25.1 \%$ & $42.4 \%$ & $0.0 \%$ & $449.1 \%$ \\
\hline 4 & 99 & $28.8 \%$ & $9.2 \%$ & $0.9 \%$ & $27.0 \%$ & $30.6 \%$ & $1.3 \%$ & $53.4 \%$ \\
\hline Total & 393 & $37.3 \%$ & $78.9 \%$ & $4.0 \%$ & $29.5 \%$ & $45.1 \%$ & $0.0 \%$ & $1342.9 \%$ \\
\hline
\end{tabular}

TABLE 8

ANOVA

\section{Average Tax Rate}

\begin{tabular}{|l|c|c|c|c|c|}
\hline & Sum of Squares & $\mathrm{df}$ & Mean Square & $\mathrm{F}$ & Sig. \\
\hline Between Groups & $30,434.47$ & 3.00 & $10,144.82$ & 1.64 & 0.18 \\
Within Groups & $2,408,627.07$ & 389.00 & $6,191.84$ & & \\
Total & $2,439,061.54$ & 392.00 & & & \\
\hline \hline
\end{tabular}

Although the F-test indicated that the results were significant to the $82 \%$ level, these results were not strong enough to conclude that there is a significant difference in average tax rates between the four quartiles. This means that there is no evidence that tax rates are related to how companies are admired by industry peers. 
TABLE 9

AVERAGE TAX RATE AND FORTUNE SOCIAL RESPONSIBILITY PEER RANK

\begin{tabular}{|c|c|c|c|c|c|c|c|c|}
\hline \multirow{2}{*}{$\begin{array}{c}\text { Quartile for } \\
\text { Social } \\
\text { Responsibility } \\
\text { Peer Rank }\end{array}$} & \multirow{2}{*}{$\mathrm{N}$} & \multirow{2}{*}{ Mean } & \multirow{2}{*}{ Std. Deviation } & \multirow{2}{*}{ Std. Error } & \multicolumn{2}{|c|}{$\begin{array}{l}95 \% \text { Confidence Interval for } \\
\text { Mean }\end{array}$} & \multirow{2}{*}{ Minimum } & \multirow{2}{*}{ Maximum } \\
\hline & & & & & Lower Bound & Upper Bound & & \\
\hline 1 & 79 & $28.3 \%$ & $8.5 \%$ & $1.0 \%$ & $26.4 \%$ & $30.2 \%$ & $0.0 \%$ & $48.1 \%$ \\
\hline 2 & 113 & $37.1 \%$ & $58.2 \%$ & $5.5 \%$ & $26.2 \%$ & $47.9 \%$ & $0.0 \%$ & $477.0 \%$ \\
\hline 3 & 92 & $31.2 \%$ & $19.3 \%$ & $2.0 \%$ & $27.2 \%$ & $35.2 \%$ & $0.5 \%$ & $119.2 \%$ \\
\hline 4 & 84 & $54.8 \%$ & $154.4 \%$ & $16.8 \%$ & $21.2 \%$ & $88.3 \%$ & $0.2 \%$ & $1342.9 \%$ \\
\hline Total & 368 & $37.7 \%$ & $81.4 \%$ & $4.2 \%$ & $29.4 \%$ & $46.1 \%$ & $0.0 \%$ & $1342.9 \%$ \\
\hline
\end{tabular}

The descriptive statistics for the Fortune Social Responsibility Peer Rank arrange the data into four quartiles based on their peer rank for social responsibility in Fortune's Most Admired Companies survey. The data shows that the fourth quartile has the largest average tax rate, however it also exhibited the largest variance out of the group. The overall average corporate tax rate of $37.7 \%$ is larger than the average for the entire data set, and closer to the $35 \%$ effective tax rate that is supposedly paid by US firms.

TABLE 10

ANOVA

Average Tax Rate
\begin{tabular}{|l|c|c|c|c|c|}
\hline & Sum of Squares & $\mathrm{df}$ & Mean Square & $\mathrm{F}$ & Sig. \\
\hline Between Groups & $35,422.50$ & 3.00 & $11,807.50$ & 1.79 & 0.15 \\
Within Groups & $2,398,404.58$ & 364.00 & $6,589.02$ & & \\
Total & $2,433,827.08$ & 367.00 & & & \\
\hline
\end{tabular}

As shown, the results were only significant to an $85 \%$ confidence level. This evidence isn't strong enough for this study to conclude there is a significant difference in how much firms from different corporate responsibility peer ratings pay in taxes. This suggests that corporate insiders do not consider the amount that firms pay in taxes to be an indicator of the Corporate Social Responsibility.

\section{Regression Analysis}

The last analysis done in this study was a fixed effects regression, which sought to utilize all the CSR metrics as explanatory variables for effective tax rate. The goal was not to fit a model for predicting tax rates, rather it was to see whether the reputation ratings had any explanatory power for tax rates. Including all the ratings (ESG, RepTrak, Fortune, and Social Responsibility Peer Rank) gives a complete picture of reputation, from the perspective of professionals, consumers, and peers. The results of the regression showed that none of the CSR metrics had a statistically significant effect on Tax Rates (see Tables 11 and 12 below). While the ESG Score had a "p" of .078, it still does not warrant the conclusion that the ESG score had a negative relationship with effective tax rates. It was interesting to note that the ESG score actually exhibited a negative relationship with Effective Tax Rates. 
TABLE 11

MODEL SUMMARY

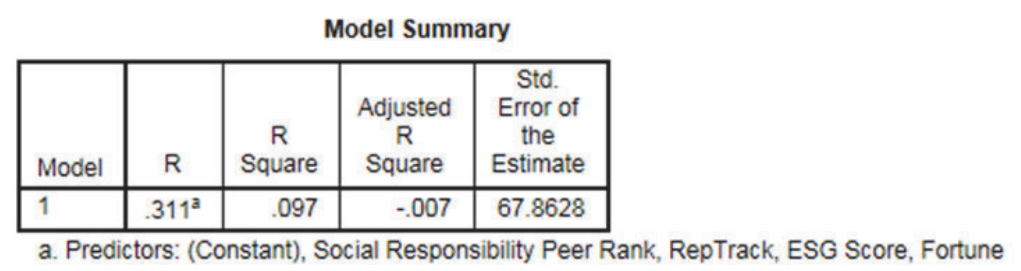

TABLE 12

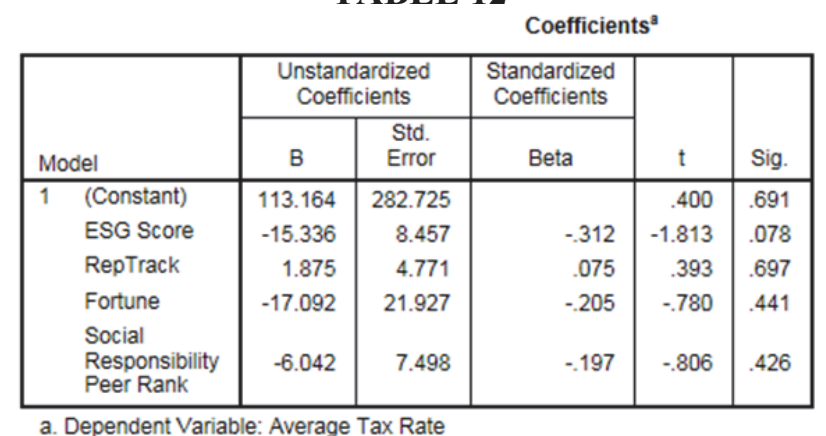

This was mostly likely a result of collinearity between the CSR ratings. Overall, the regression analysis was not helpful for proving any relationship between CSR and taxes.

\section{CONCLUSIONS}

The result of this empirical study provides valuable insight into the relationship (or lack thereof) between corporate taxes and CSR ratings. By carefully picking CSR ratings from the perspective of peer companies (Fortune), professional CSR evaluators (MSCI ESG), and public opinion (RepTrak), this study was able to evaluate different perspectives of social responsibility.

Evaluating the correlations between the various CSR ratings and metrics such as Cash Taxes Paid and Average Effective Tax Rate provided a foundation for understanding this issue. The lack of correlation between each CSR rating and the corporate tax rate was not a promising start for the study. To further dive into this relationship, the study broke out each rating into quartiles to judge whether there was a positive or negative relationship within peer CSR groups. What followed was a series of results that suggested no significant differences occurred in the mean effective tax rate between quartile groups in each CSR category. Lastly, a regression analysis was done for good measure. The results were ultimately inconclusive due to collinearity between the CSR ratings.

The lack of statistically significant relationships between Corporate Social Responsibility and Tax Rates suggests different things for each rating stakeholders. For the RepTrak ratings, it could either suggest that consumers are ignorant to how much different firms pay in taxes, or it could suggest that consumers do not care about whether companies pay their fair share of taxes. For the Fortune ratings, the results suggest that peer businesses do not regard taxes when evaluating firm reputations. This could be an indication of their own preferences to avoid taxes, or could simply indicate their preference of other key measure, such as profitability to outweigh any tax avoidance by corporations. Lastly, the ESG ratings showed that the professional rating agency weighed other ESG factors, such as environmental impact or labor management, more than how much firms pay in taxes. This is clearly evident in the study, which didn't include a direct category for taxes in the calculation of ESG scores.

A general lack of consideration for corporate tax rates is a common theme across these CSR ratings. Given the recent social movements in holding firms accountable for paying their fair share of taxes, it is 
somewhat alarming that certain firms are getting away with tax avoidance, and not being held responsible for it by any major stakeholder group. This suggests better measurement from professional rating agencies such as MSCI is appropriate, and also suggests that firms should be exposed by the media for tax evasion, so as to better educate the public on this issue.

\section{REFERENCES}

Elam, D. (2016). World's Most Admired Companies. Retrieved from http://fortune.com/worlds-mostadmired-companies/

Kilkenny, A. (2012). Hundreds Protest America's Crooked Tax System. Retrieved May 8, 2016, from http://www.thenation.com/article/hundreds-protest-americas-crooked-tax-system/)

Lee, L-E. (2015). A Modern Strategy: Integrating Sustainability to Investment Decision Making. Retrieved from http://www.factset.com/files/symposium2015/Markets_Lee

McIntyre, R., Gardner, M., Wilkins, R., \& Phillips, R. (2011). Corporate Taxpayers and Corporate Tax Dodgers 2008-10. A Joint Project of Citizens for Tax Justice \& the Institute on Taxation and Economic Policy, 1-15.

MSCI. (2016). MCSI ESG Direct. Retrieved from https://esgoncampus-msci-com.proxy.bc.edu.

Pomerleau, K. (2015). Corporate Income Tax Rates around the World, 2015. Retrieved May 8, 2016, from http://taxfoundation.org/article/corporate-income-tax-rates-around-world-2015

RepTrak Institute. (2016). Who are the Most Reputable Companies in the World in 2016? Retrieved from https://www.reputationinstitute.com/research/Global-RepTrak-100

Thorndike, J. (2012). The Durability of a Dysfunctional Tax: Public Opinion and the Failure of Corporate Tax Reform. The Kansas Journal of Law and Public Policy, 347-350.

Turner, L. (2013, July 11). MSCI KLD Scores. Retrieved from http://nbs.net/knowledge/kld-scores/ 